Article

\title{
Linking Hydrologic and Hydraulic Data with Models to Assess Flow and Channel Alteration at Hog Park, Wyoming USA
}

\author{
Tyler J. Carleton ${ }^{1}$ and Steven R. Fassnacht $1,2,3, * \mathbb{D}$ \\ 1 ESS-Watershed Science, Colorado State University, Fort Collins, CO 80523-1476, USA; \\ tyler.carleton@usda.gov \\ 2 Cooperative Institute for Research in the Atmosphere, Fort Collins, CO 80523-1375, USA \\ 3 Natural Resources Ecology Laboratory, Fort Collins, CO 80523-1499, USA \\ * Correspondence: steven.fassnacht@colostate.edu; Tel.: +1-970-491-5454
}

Received: 27 April 2020; Accepted: 21 May 2020; Published: 23 May 2020

\begin{abstract}
Transbasin diversions and dams allow for water uses when and where there is high demand and low supply, but can come with an expense to the environment. This paper presents a linkage of hydrologic and hydraulic modeling and datasets to assess the hydrologic and hydraulic stability within a transbasin watershed as an approach for meeting water use targets and safeguarding environmental sustainability. The approach used a Prediction in Ungauged Basin (PUB) regionalization technique that completed the parameterization of a study watershed hydrologic model by transferring calibrated parameters from a reference watershed hydrologic model. This resulted in a long-term, simulated natural flow record that was compared to the measured modified flow record for the same time period to assess flow alteration. In the sensitive reach, hydraulic modeling results tracked channel response from before hydrologic modification to baseline using repeated survey years during the hydrologic modification. The combined assessment of hydrology and hydraulics highlighted the relation between flow regime and channel form.
\end{abstract}

Keywords: hydrologically modified watershed; hydrologic model; hydraulic model; transbasin diversion; reservoir; land use management; prediction in ungauged basin (PUB)

\section{Introduction}

Across the world, transbasin diversions move large volumes of water from one river basin to another, and major dams impound and store water for later use [1]. These large-scale water collection systems allow for the beneficial use of water when and where there is high demand and low supply. However, the benefits may come at the expense of the environment, and the extent is not fully understood [2]. Though environmental analyses for such projects may have been completed to minimize potential adverse effects, some were difficult to predict and persisted many decades later [3-5]. As the supply and demand for water changes, whether due to climate change, land use change, or population growth, there is a pressing need to better understand the balance of vital water resource objectives and environmental sustainability.

The environmental effects from extensive water collections systems are influenced by the changes in hydrology. The changes in hydrology occur as a result of water being augmented to or diverted from a basin, stored behind dams, and released at different rates, magnitudes, and times throughout the year. This study analyzes the scenario at Hog Park, Wyoming (Figure 1) where a major dam stores the water received from a transbasin diversion. One result is downstream channel enlargement [6]. 


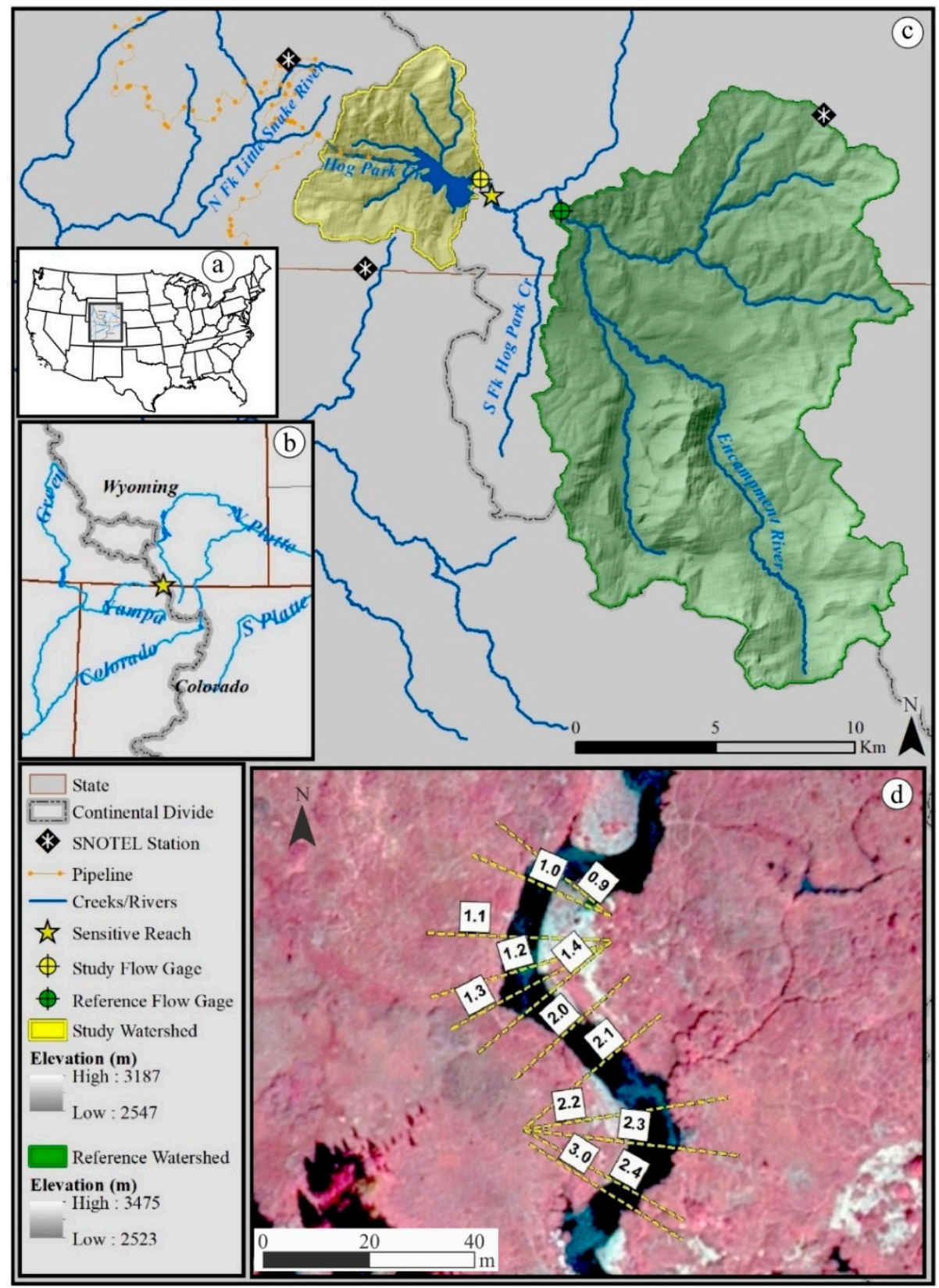

Figure 1. (a) The states of Wyoming and Colorado located within USA. (b) An inset map of the Hog Park study site area in the states of Wyoming and Colorado, USA; Continental Divide; and major rivers. (c) An overview map of the study and reference watersheds, sensitive reach, SNOTEL niveo-meteorological stations, Hog Park Creek, Encampment River, North Fork Little Snake River, transbasin diversion pipeline, Hog Park Reservoir, study watershed flow gage, and reference watershed flow gage. (d) A planform view of the sensitive reach of the study watershed selected for geometry surveys including cross-sections (numbers 0.9-3.0).

Transbasin diversions have been found to increase intermediate and low flows in the receiving basin, such as the Kemano River in central British Columbia that receives water from the Nechako River for hydroelectric power generation [7], and the Milk River in Montana, which receives water from the Saint Mary River in Alberta [8]. Similarly, a 10-fold increase in low flows was observed at the River Ter, UK, which receives water from groundwater pumped to Leighs Reservoir [9]. These studies indicated that increased low and intermediate flows can play a key role in channel enlargement. On smaller rivers, peak flows can play a role in channel enlargement due to flow alteration from 
transbasin diversion and dam storage, such as diversion from the Colorado River headwaters to La Poudre Pass Creek of the Poudre River where a combination of increased peak flows and decreased low flows contribute to channel enlargement [10]. Peak flows were double, with longer duration on the Lake Creek and the Lake Fork of the Arkansas River, which receive water from the Roaring Fork of the Colorado River, resulting in more than fifty years of channel enlargement, as well as substantially decreased riparian cover area [11]. In the Owens River of California, which receives water from the nearby Mono Basin, increased flood magnitude, frequency, and duration resulted in a decrease in annual growth rates of willows, with the best willow growth rates spurred from floods in the high range of natural flooding and a low range of the modified flooding [12]. Together, these studies indicate that changes in hydrology play a key role in channel enlargement, as well as the associated loss of riparian ecosystems.

The changes in hydrology have been estimated using a framework known as predictions in ungauged basins (PUB). PUB utilizes a regionalization of hydrologic process knowledge to understand hydrologic response in ungauged basins [13]. Regional regression methods can be used to estimate ungauged, natural flow characteristics. The regional regression equations derived from the USGS flood flow frequency analysis method [14] are published for most regions in the US, including the mountainous regions of Wyoming, but have a high standard error [15]. Locally developed multiple regression models have demonstrated the potential for accurate estimates of natural flow regime metrics [16]. Reference sites that have spatially and physically similar proxies and have a long-term, measured, natural flow record can be used to estimate natural flow attributes [17]. Furthermore, the attributes of natural hydrologic processes from a reference watershed can be transferred to a hydrologically modified study watershed based on the close spatial proximity and physical similarity [18]. One application of the latter regionalization technique is to parameterize a hydrologic model of a hydrologically modified study watershed to simulate a natural flow record $[19,20]$.

In response to a change in hydrology, a channel changes cross-sectional, plan, and profile geometry. The progression of this channel change can be assessed using measured channel geometry data for a long-term period of time and hydraulic modeling. A hydraulic model simulates flow characteristics in a channel or through a network of multiple channels [21]. For hydraulic properties, such as water surface elevations, wetted perimeters, and flood inundation area, the hydraulic model uses the measured channel geometry data [22]. Hydraulic models of sequential years show the progression of hydraulic changes. An improved method to concurrently assess hydrologic and hydraulic stability could provide a tool to inform managers on how to simultaneously meet water resource targets and safeguard environmental sustainability. Towards this purpose, the study objectives are: (1) use PUB methods to simulate long-term natural flow in a hydrologically modified watershed without a measured, natural flow record, but with a measured, modified flow record; (2) use channel geometry data from sequential years to model the long-term hydraulic response of a sensitive reach within the hydrologically modified watershed; and (3) assess relations between the flow regime and channel response in a hydrologically modified watershed. The unique constraints that lead to this type of assessment are: (1) limited long-term flow data to understand flow regime alteration in hydrologically modified watersheds, and (2) limited long-term channel geometry data to understand channel response in hydrologically modified watersheds. This approach recognizes that establishing a new long-term, modified flow regime and channel form that are both in harmony may be more practical than returning hydrologically modified systems to their natural state.

\section{Study Site}

The Hog Park study area is in the Sierra Madre Range in the Southern Rocky Mountains (Figure 1). Glaciation, fluvial processes, climate, and dam management helped shape the area. Moderate to deep loamy-skeletal soils and steep, forested hillslopes are underlain by a Precambrian igneous and metamorphic geology $[23,24]$. The climate consists of cold winters and cool summers where the bulk of precipitation falls as snow, with a median peak snow water equivalent of about $760 \mathrm{~mm}$ and an 
average annual precipitation of about $1080 \mathrm{~mm}$, as measured at the nearby USDA NRCS Whiskey Creek snow telemetry (SNOTEL) site [25].

The Hog Park study site encompasses a reference watershed, study watershed, and study watershed sensitive reach (Figure 1). The reference watershed is the Encampment River drainage above its confluence with Hog Park Creek and is considered mostly pristine with minor anthropogenic influences due to its location in designated wilderness [26]. The study and reference watersheds are in close spatial proximity and consequently share similar climate, geology, and land cover. Notable differences in the study watershed are a large reservoir with a storage capacity of $3.08 \times 10^{7} \mathrm{~m}^{3}$ and large transbasin diversion which receives water piped through the Continental Divide from 126 diversion structures on the North Fork of the Little Snake River. Other differences include drainage area, aspect, elevation, and percent land cover types (Table 1). A sensitive reach is located within a large, unconfined valley downstream of the main dam on Hog Park Creek (Figure 1).

Table 1. Watershed characteristic differences at the Study Watershed (Hog Park Creek above Hog Park Dam) and Reference Watershed (Encampment River above Hog Park Creek).

\begin{tabular}{ccc}
\hline Watershed Characteristic & Study Watershed & Reference Watershed \\
\hline Drainage Area [km $]$ & 32 & 189 \\
Aspect (E, W, N, S) [\%] & $33,15,21,31$ & $21,32,24,23$ \\
Elevation (Min, Max) [m] & 2550,3200 & 2520,3450 \\
Pinus contorta [\%] & 40 & 26 \\
Picea engelmanii- Abies lasiocarpa [\%] & 14 & 48 \\
Populus tremuloides [\%] & 1 & 1 \\
Upland-, Wet- Shrub [\%] & 0,0 & 0,1 \\
Wet-, Upland- Graminoid [\%] & 1,15 & 3,10 \\
Forb [\%] & 22 & 10 \\
Rock, Water [\%] & 0,7 & 1,0 \\
\hline
\end{tabular}

\section{Methodology}

To understand the effects of hydrologic modification in the study watershed, hydrologic and hydraulic data were linked with models. The first step was collating the overlapping long-term hydrologic and hydraulic data that were used to parameterize hydrologic and hydraulic models. The Precipitation-Runoff Modeling System (PRMS) hydrologic model $[27,28]$ was selected to simulate natural flows. The Hydrologic Engineering Center River Analysis System (HEC-RAS) hydraulic model [29] was selected to simulate the effects of channel change over time. The parallel results of flow and channel change indicated the cause-and-effect relation between hydrologic modification and channel form. This relation was assessed to identify the desired, stable hydrologically modified flow regime and channel form. The individual components of the approach are detailed below and are summarized in Figure 2. To achieve this, these in situ data are necessary: (1) measured modified flows at the study watershed, (2) measured natural flows at the reference watershed, and (3) baseline and repeat stream surveys of the sensitive reach at the study watershed (Figure 1). 


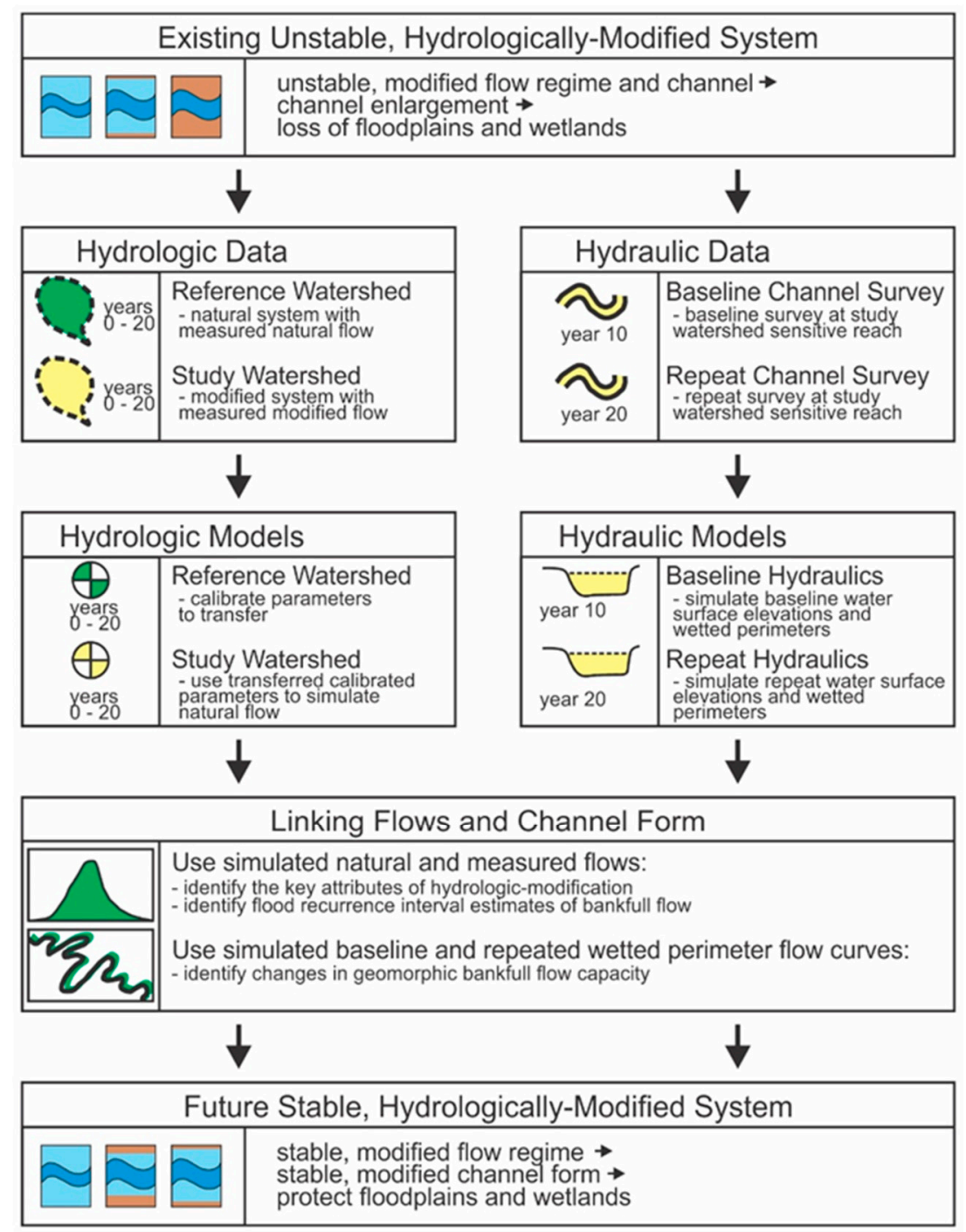

Figure 2. Schematic outlining the method used to assess an existing, unstable, hydrologically modified system. Flow and channel alteration were assessed using a combination of hydrologic and hydraulic data with models to identify a desired, future, stable, hydrologically modified system.

Measured natural flows and stream surveys of the sensitive reach at the study watershed do not exist prior to hydrologic modification, which occurred in the 1960s, following the construction of the water collection system and again in the 1980s following enlargement of that system. The current system became fully operational by 1987 (Table A1). Expanding upon the unique constraints of this assessment, two explicit assumptions were made: (1) natural flows simulated for the study watershed for the period 1995-2015 will also be considered representative for the previous years, and (2) in the absence of geometric surveys for a period before the hydrologic modification, remnant features will be defined and used. The reliability of these remnant features as representative of pre-modification discharges shall also be discussed in light of the modification date.

The specific data selected begins with availability of the modified flow record at the study watershed, which were measured by the Wyoming State Engineer and Cheyenne Board of Public Utilities [30]. Daily average flow for the period 1995 to 2015 were used. The beginning of the water year (WY) was set on October 1st, following the standard used in the U.S. Measured natural flows at the reference watershed were measured as part of the USGS Hydrologic Benchmark Network, due to its long-term, unregulated flow record [31]. Daily average flow for the same time period as the study watershed measured modified flow dataset were used. Sensitive reach stream survey data from 2006 
were repeated in 2015 after a long, continuous period of hydrologic modification. The baseline and repeat survey data included cross-sections (XSs), reach lengths between XSs, longitudinal profiles, and pebble counts. Approximately a dozen XSs were spaced out to capture two meander wavelengths of the sensitive reach. A longitudinal profile identified the hydraulic grade controls and slopes throughout the sensitive reach.

Two applications of the hydrologic model were required to simulate the reference watershed and then the study watershed (Figure 2). PRMS is a deterministic, distributed-parameter, physically based model that uses distributed parameters over sub-watersheds called hydrologic response units (HRUs) $[27,28]$. For each HRU, PRMS balanced energy and water budgets of the snowpack, plant canopy, and soil zone to simulate hydrologic processes including snowmelt, sublimation, interception, infiltration, evapotranspiration (ET), interflow, groundwater (GW) flow, and surface runoff [28].

The key input variables for each application of PRMS included temperature (T), precipitation (P), solar radiation (SR), and ET. The T and P data were obtained from NRCS SNOTEL stations [25] surrounding the study area (Figure 1). The $\mathrm{T}$ and $\mathrm{P}$ data were distributed using three-dimensional multiple-linear regression based on latitude, longitude, and elevation [32]. The SR data were estimated by a degree-day relation [33]. These SR data estimates were then adjusted using daylight hours, days with P, and potential SR [34]. The ET data were estimated using the modified Jensen-Haise method and then distributed based on plant cover, soil properties, and potential ET (PET) [33,34]. In addition to distributing climate input variables, unique geospatial parameter values were extracted from stream network, land cover, canopy density, soils, elevation, slope, aspect, and radiation plane data with the GIS Weasel program [35].

The parameterization process for the reference watershed was automated by the Let Us Calibrate (LUCA) multiple-objective, stepwise calibration method. This method calibrated model variables (e.g., SR; ET; and monthly, daily, low, and high flows) against measured datasets over a ten-year calibration period (2006-2015) by adjusting the model parameter values [32]. These measured datasets used for calibration included global horizontal irradiance [36], actual ET [37], and daily average flow [31]. The parameter values used in each step were selected based on the sensitivity analysis conducted by the USGS on the adjacent Yampa River basin for snowmelt dominated basins [32]. LUCA calculated one parameter value for the watershed by averaging across all HRUs as opposed to for each HRU. LUCA calculated the accuracy of the modeled variables compared to the measured datasets using two objective functions, sum of the absolute difference in logarithms and normalized root mean square error [32]. The final parameter values were set after six rounds of six steps (Table 2). Each step continued until the objective functions made no improvement in accuracy following a series of parameter value adjustment iterations. With the final parameters (Table A2), the model was run for a separate ten-year evaluation period (1996-2005) to test the parameterization. Nash-Sutcliffe Efficiency (NSE) [38] and Percent Bias (PBIAS) were used as metrics for determining satisfactory overall model performance $[38,39]$.

The last step of the parameterization process adjusted all the parameters that could be recalculated using values derived from the unique characteristics from the study watershed. These adjusted parameters included those relating to site-specific land cover, elevation, aspect, stream network, and climate characteristics. There were 21 sensitive parameters obtained from a reference watershed parameterization that could not be recalculated, such as coefficients for routing groundwater and snowmelt (Table 2). Utilizing both the adjusted parameter values from the study watershed parameterization and the 21 unadjusted parameters obtained from reference watershed parameterization, the study watershed natural flow dataset was simulated. 
Table 2. The 21 sensitive parameters listed by each step of the LUCA tool for the PRMS hydrologic model. The final sensitive parameter values of reference watershed hydrologic model parameterization were transferred to complete the study watershed parameterization.

\begin{tabular}{|c|c|c|c|}
\hline Step & Calibration Data & Parameter & Parameter Description \\
\hline \multirow{2}{*}{1} & \multirow{2}{*}{ Average monthly SR } & dday_intcp & $\begin{array}{l}\text { Intercept in T } \\
\text { degree-day relationship }\end{array}$ \\
\hline & & tmax_index & $\begin{array}{l}\text { Index T used for P adjustments } \\
\text { to SR }\end{array}$ \\
\hline 2 & Basin average monthly ET & jh_coef & $\begin{array}{l}\text { Coefficient used in the } \\
\text { Jensen-Haise PET computations }\end{array}$ \\
\hline \multirow{2}{*}{3} & \multirow{2}{*}{$\begin{array}{l}\text { Average annual flow, Average monthly } \\
\text { flow, and Monthly average flow }\end{array}$} & adjust_rain & $\mathrm{P}$ adjustment factor for rain days \\
\hline & & adjust_snow & $P$ adjustment factor for snow days \\
\hline \multirow{10}{*}{4} & \multirow{10}{*}{ Daily flow } & adjmix_rain & $\begin{array}{l}\text { Factor to adjust rain in mixed } \\
\text { P events }\end{array}$ \\
\hline & & cecn_coef & $\begin{array}{l}\text { Convection condensation } \\
\text { energy coefficient }\end{array}$ \\
\hline & & emis_noppt & $\begin{array}{l}\text { Emissivity of air on days } \\
\text { without } P\end{array}$ \\
\hline & & free_h20cap & $\begin{array}{l}\text { Free water holding capacity } \\
\text { of snowpack }\end{array}$ \\
\hline & & potet_sublim & $\begin{array}{l}\% \text { PET sublimated from the } \\
\text { snowpack surface }\end{array}$ \\
\hline & & slowcoef_lin & $\begin{array}{l}\text { Linear coefficient in the equation } \\
\text { to route gravity-reservoir } \\
\text { storage downslope }\end{array}$ \\
\hline & & slowcoef_sq & $\begin{array}{l}\text { Exponent in the equation to route } \\
\text { gravity-reservoir } \\
\text { storage downslope }\end{array}$ \\
\hline & & snowinfil_max & $\begin{array}{l}\text { Daily max. snowmelt infiltration } \\
\text { for the hydrologic response } \\
\text { units (HRU) }\end{array}$ \\
\hline & & tmax_allrain & $\begin{array}{l}\text { If a HRU max. T exceeds this } \\
\text { value, } P \text { is rain }\end{array}$ \\
\hline & & tmax_allsnow & $\begin{array}{l}\text { If a } \mathrm{HRU} \text { max. } \mathrm{T} \text { is below this } \\
\text { value, } \mathrm{P} \text { is snow }\end{array}$ \\
\hline \multirow{2}{*}{5} & \multirow{2}{*}{ Peak flow } & smidx_coef & $\begin{array}{l}\text { Coefficient in non-linear surface } \\
\text { runoff contributing area algorithm }\end{array}$ \\
\hline & & smidx_exp & $\begin{array}{l}\text { Exponent in non-linear surface } \\
\text { runoff contributing area algorithm }\end{array}$ \\
\hline \multirow{4}{*}{6} & \multirow{4}{*}{ Low flow } & gwflow_coef & GW routing coefficient \\
\hline & & soil2gw_max & $\begin{array}{l}\text { Max. rate of soil water excess } \\
\text { moving to GW }\end{array}$ \\
\hline & & ssr2gw_exp & $\begin{array}{l}\text { Exponent to route water from the } \\
\text { gravity-reservoir to } \\
\text { groundwater (GW) }\end{array}$ \\
\hline & & ssr2gw_rate & $\begin{array}{l}\text { Linear coefficient to route water } \\
\text { from the gravity-reservoir to GW }\end{array}$ \\
\hline
\end{tabular}

The HEC-RAS hydraulic model [39] was parameterized for using both the baseline and repeat stream surveys of the sensitive reach (Figure 1). The inputs included slope, XS geometry, reach lengths between XSs, and Manning's n estimates. The average bed slope, which approximated the energy slope, was used as the downstream boundary condition for the model. The active channel Manning's $n$ value was initially estimated using flow depth and grain size from pebble count data [40]. Additional roughness from bank irregularities along the reach was added to the initial active channel Manning's $n$ 
value [41]. The floodplain Manning's n value estimates were obtained from the table values of winter and summer, medium-to-dense brush [42].

A range of representative high flows were selected for the hydraulic models. The range of representative high flows were the 1-year to 20-year recurrence intervals calculated from the study watershed simulated natural daily average flows. For each flow between the 1- and 20-year recurrence intervals, the hydraulic model computed a corresponding water surface elevation as well as other hydraulic data such as wetted perimeter and flood inundation area.

Using the hydrologic and hydraulic data with models allowed the concurrent assessment of the flow and channel alteration in response to hydrologic modification (Figure 2). Flow alteration was indicated by comparing the attributes of simulated natural flows to measured modified flows using the Indicators of Hydrologic Alteration (IHA) tool [43]. IHA calculates a deviation factor to express the magnitude of change between pre- and post-impact periods. Deviation factor is calculated by taking the absolute value of the difference between the post-impact and pre-impact values and then dividing by the pre-impact value. To measure the significance of the deviation, IHA calculates a significance count for the deviation values by randomly shuffling all years of input data and recalculating fictitious pre- and post-impact medians 1000 times. The significance count is the number of fictitious deviation values that are greater than for the actual deviation factor out of 1000. If this fraction is close to zero, it means that the deviation is highly significant [43]. As a way to characterize the connection between flow and channel alteration, bankfull flows were analyzed. Specifically, the flood recurrence interval estimates of bankfull flow from pre- and post- hydrologic modification were compared to geomorphic estimates of bankfull capacity. This method is described in more detail below.

The key attributes of flow alteration were the monthly magnitudes, magnitude and duration of annual extremes, the timing of annual extremes, frequency and duration of pulse flows, rate and frequency changes, recurrence intervals, and snowmelt period flood characteristics. The snowmelt period was identified as the subset of the annual hydrograph from the onset of the rising limb to the terminus of the falling limb.

Since the channel was in a state of disequilibrium, the visual estimates of bankfull elevation at each XS were inconsistent within the sensitive reach (Figure 1). While surveying the sensitive reach, reliable indicators of bankfull stage were difficult to find due to the amount of channel change. Instead, the geomorphic bankfull for each XS was estimated using wetted perimeter-flow curves [22]. A curve for each XS, for both 2006 and 2015, was plotted using the simulated wetted perimeter against flow. The geomorphic bankfull was indicated on the curve by a break in slope, called a major breakpoint. Conceptually, a major breakpoint represents the threshold where the water within the active channel reaches the top of the stream bank and spills into the floodplain, thereby substantially increasing the wetted perimeter for negligible increases in flow. A subtler break in slope, called a minor breakpoint, likely indicated a remnant geomorphic bankfull. While one could mathematically approximate the breakpoints by curve fitting, we visually determined them, which yielded a possible error of 0.1 to $0.2 \mathrm{~m}^{3} / \mathrm{s}$.

Drawn from the evidence that channel form responds to flow, the existing channel may be brought into a quasi-equilibrium near its current geomorphic capacity by defining a corresponding hydrologically modified flow regime that is stable over a long-term period. The attributes for this new, stable, modified flow regime incorporated the flow attributes of the existing geomorphic channel capacity and the simulated natural flow regime where possible. The attributes that were defined included the frequency, magnitude, duration, rise rate, fall rate, and timing for low, intermediate, and peak flows. A range of variability was applied to the attributes of the new, stable, modified flow regime to accommodate dry, average, and wet years. Namely, the attributes of the new, stable, modified flow regime bounded the hydrologically modified flow regime to promote stabilization of the existing channel over a long-term period of time. In doing so, this provides a means to both meet water resource objectives and protect environmental sustainability. 


\section{Results}

The reference watershed hydrologic model parameterization had a ten-year evaluation period NSE of $0.82 \%$ and PBIAS of $-4.5 \%$, as compared to the ten-year calibration period NSE of 0.89 and PBIAS of $-1.9 \%$. The simulated streamflow matched the observed streams at the reference well for average, high and low flow years (Figure 3). The individual years each had NSE above $60 \%$ and PBIAS within $20 \%$. The lower NSE values in individual years indicated that snowmelt runoff was simulated early or late. The higher PBIAS values in individual years indicated the simulated total annual runoff volume was overestimated or underestimated. With satisfactory model performance [39], the final parameters values were selected for use in the study watershed hydrologic model application.

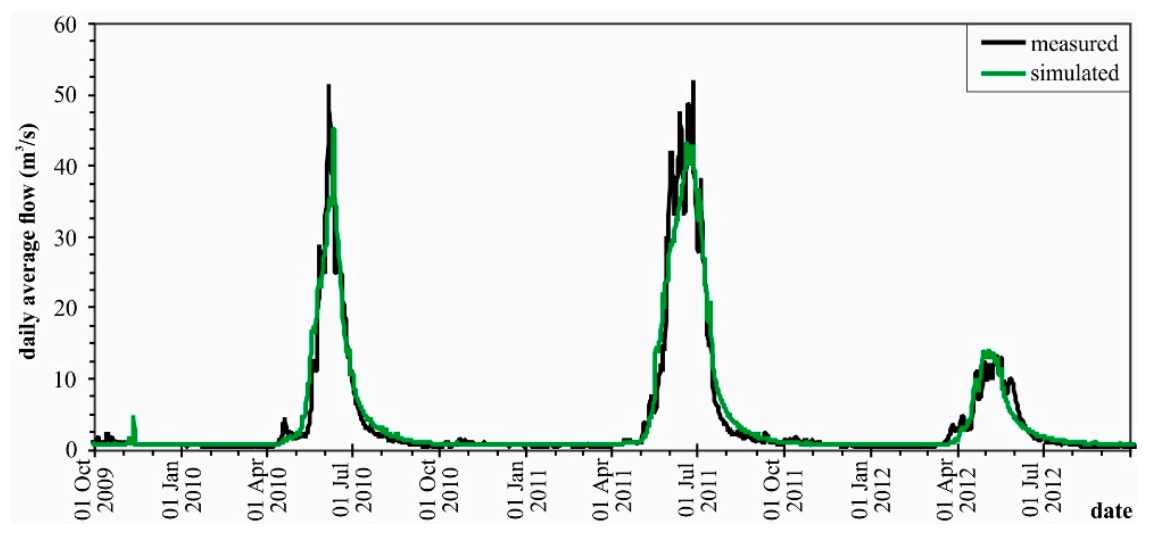

Figure 3. Simulated natural and measured modified daily average flow for the reference watershed for a subset of the time period showing average (2010), wet (2011), and dry years (2012).

The parameterization of the study watershed hydrologic model simulated daily average flows from 1995-2015. A comparison with the measured modified flows indicated hydrologic modifications, specifically the later timing of peak flows, lower peak flows, and lower low flows, especially in the winter (Figure 4a and Table 3); further cumulative volumes were less (Figure 4b). The most altered attributes were low flows and monthly flows in the winter and spring (Table 3). To a slightly lesser degree, other attributes were lowered, including flood frequency, magnitude, duration, timing (later), and fall rates (Table 3). Channel change assessed by tracking geomorphic bankfull capacity was indicated by the minor and major breakpoints on the wetted perimeter-flow curves (Figure 5). The minor breakpoints in 2006 (Figure $5 \mathrm{a}$ ) and again in 2015 (Figure $5 \mathrm{~b}$ ) were 3.7 to $4.0 \mathrm{~m}^{3} / \mathrm{s}$. The major breakpoints were 4.6 to $4.8 \mathrm{~m}^{3} / \mathrm{s}$ in 2006 and then 5.4 to $5.6 \mathrm{~m}^{3} / \mathrm{s}$ in 2015 .

The comparison of recurrence interval for the bankfull flow to the geomorphic bankfull capacity indicated a cause-and-effect relation between the flow regime and channel form. The close agreement of the remnant geomorphic bankfull capacity indicated by minor breakpoints in 2006 and 2015 of $3.9 \mathrm{~m}^{3} / \mathrm{s}$ (Figure 5) and the 1995-2015 simulated natural 1.5-year flood of $3.8 \mathrm{~m}^{3} / \mathrm{s}$ (Figure 6) suggested a channel that was in equilibrium prior to hydrologic modification. The close agreement of the existing

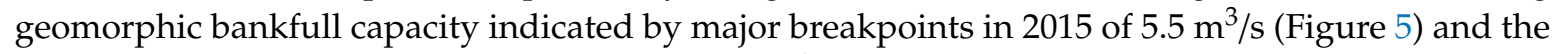
1987-2015 measured modified 1.5-year flood of $5.8 \mathrm{~m}^{3} / \mathrm{s}$ (Figure 6) suggested that the channel has nearly finished enlarging to accommodate an increase in flows from a long period of hydrologic-modification. Alternatively, if the 2015 existing channel is on a tendency closer to the 1995-2015 measured modified 1.5 -year flood of $7.6 \mathrm{~m}^{3} / \mathrm{s}$ (Figure 6), then continued enlargement may be anticipated. 


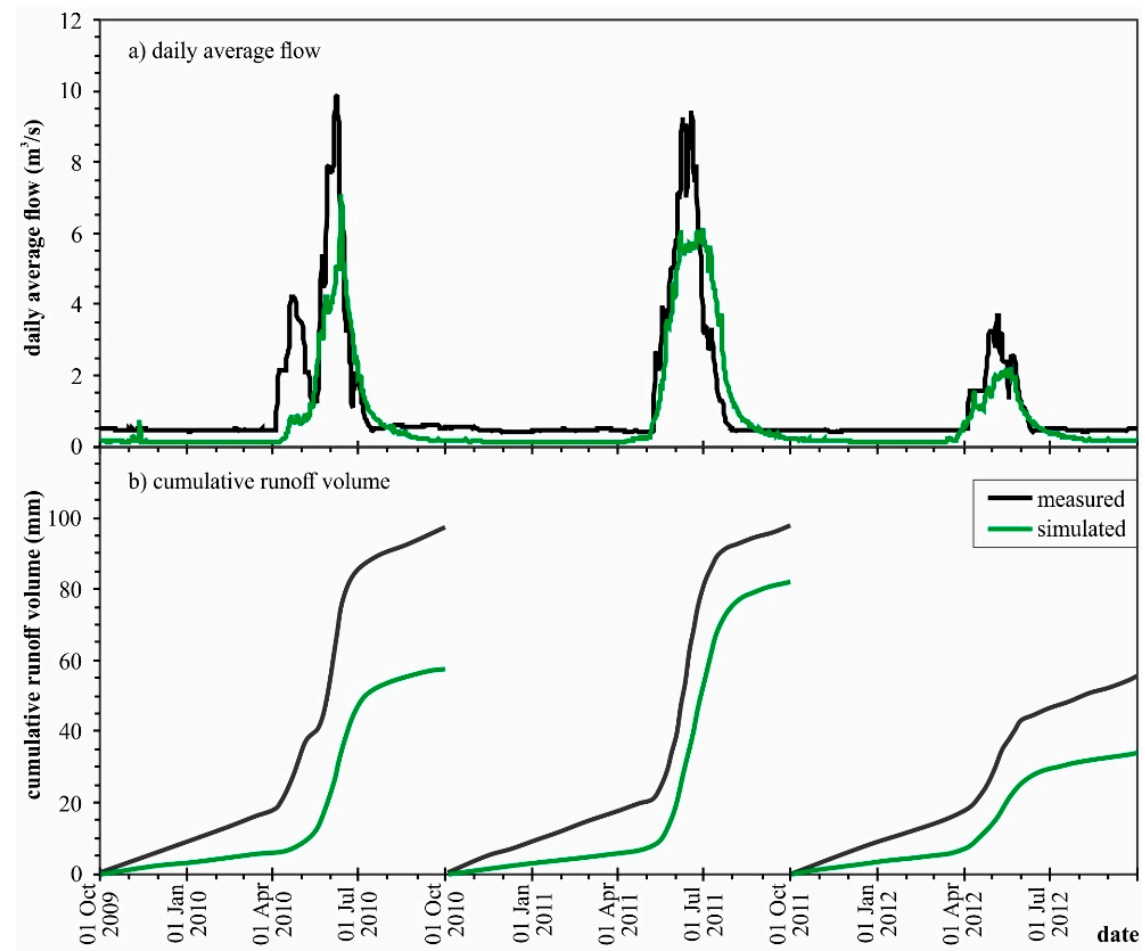

Figure 4. Simulated natural and measured modified (a) daily mean and (b) cumulative daily average flows for the study watershed for the subset of the time period shown in Figure 3.

Table 3. Comparison of the simulated natural and measured modified flow attributes to assess the degree of alteration using a deviation factor and the significance of the alteration, ranging from highly significant (0) to not significant (1).

\begin{tabular}{|c|c|c|c|c|}
\hline Flow Attribute & $\begin{array}{l}\text { Meas. Modified Flow } \\
\text { (Median) }\end{array}$ & $\begin{array}{l}\text { Sim. Natural Flow } \\
\text { (Median) }\end{array}$ & $\begin{array}{l}\text { Deviation } \\
\text { Factor }\end{array}$ & $\begin{array}{l}\text { Significance } \\
\quad(0 \text { to } 1)\end{array}$ \\
\hline \multicolumn{5}{|c|}{ Monthly Flow Attributes } \\
\hline October $\left(\mathrm{m}^{3} / \mathrm{s}\right)$ & 0.48 & 0.17 & 1.9 & 0 \\
\hline November $\left(\mathrm{m}^{3} / \mathrm{s}\right)$ & 0.48 & 0.15 & 2.1 & 0 \\
\hline December $\left(\mathrm{m}^{3} / \mathrm{s}\right)$ & 0.47 & 0.15 & 2.2 & 0 \\
\hline January $\left(\mathrm{m}^{3} / \mathrm{s}\right)$ & 0.47 & 0.14 & 2.3 & 0 \\
\hline February $\left(\mathrm{m}^{3} / \mathrm{s}\right)$ & 0.50 & 0.14 & 2.5 & 0 \\
\hline $\operatorname{March}\left(\mathrm{m}^{3} / \mathrm{s}\right)$ & 0.51 & 0.14 & 2.7 & 0 \\
\hline April $\left(\mathrm{m}^{3} / \mathrm{s}\right)$ & 1.13 & 0.35 & 2.2 & 0 \\
\hline May $\left(\mathrm{m}^{3} / \mathrm{s}\right)$ & 3.22 & 1.95 & 0.7 & 0 \\
\hline June $\left(\mathrm{m}^{3} / \mathrm{s}\right)$ & 3.35 & 3.10 & 0.1 & 0.7 \\
\hline July $\left(\mathrm{m}^{3} / \mathrm{s}\right)$ & 0.52 & 0.66 & 0.2 & 0.3 \\
\hline August $\left(\mathrm{m}^{3} / \mathrm{s}\right)$ & 0.49 & 0.30 & 0.6 & 0 \\
\hline September $\left(\mathrm{m}^{3} / \mathrm{s}\right)$ & 0.47 & 0.20 & 1.4 & 0 \\
\hline \multicolumn{5}{|c|}{ Annual Flow Attributes (water year from Oct. 1 to Sep. 30) } \\
\hline 7-day Low $\left(\mathrm{m}^{3} / \mathrm{s}\right)$ & 0.44 & 0.13 & 2.3 & 0 \\
\hline Annual Peak $\left(\mathrm{m}^{3} / \mathrm{s}\right)$ & 8.0 & 4.6 & 0.7 & 0 \\
\hline \multicolumn{5}{|c|}{ Flood Attributes (the period from the start of the rising limb to the end of the falling limb) } \\
\hline Peak $\left(\mathrm{m}^{3} / \mathrm{s}\right)$ & 8.0 & 5.1 & 0.5 & 0 \\
\hline Duration $(\mathrm{d})$ & 103 & 93 & 0.1 & 0.1 \\
\hline Date of Peak & May 26 & June 6 & 0.1 & 0 \\
\hline Rise Rate $\left(\mathrm{m}^{3} / \mathrm{s} / \mathrm{d}\right)$ & 0.14 & 0.10 & 0.3 & 0 \\
\hline Fall Rate $\left(\mathrm{m}^{3} / \mathrm{s} / \mathrm{d}\right)$ & -0.16 & -0.09 & 0.7 & 0 \\
\hline
\end{tabular}




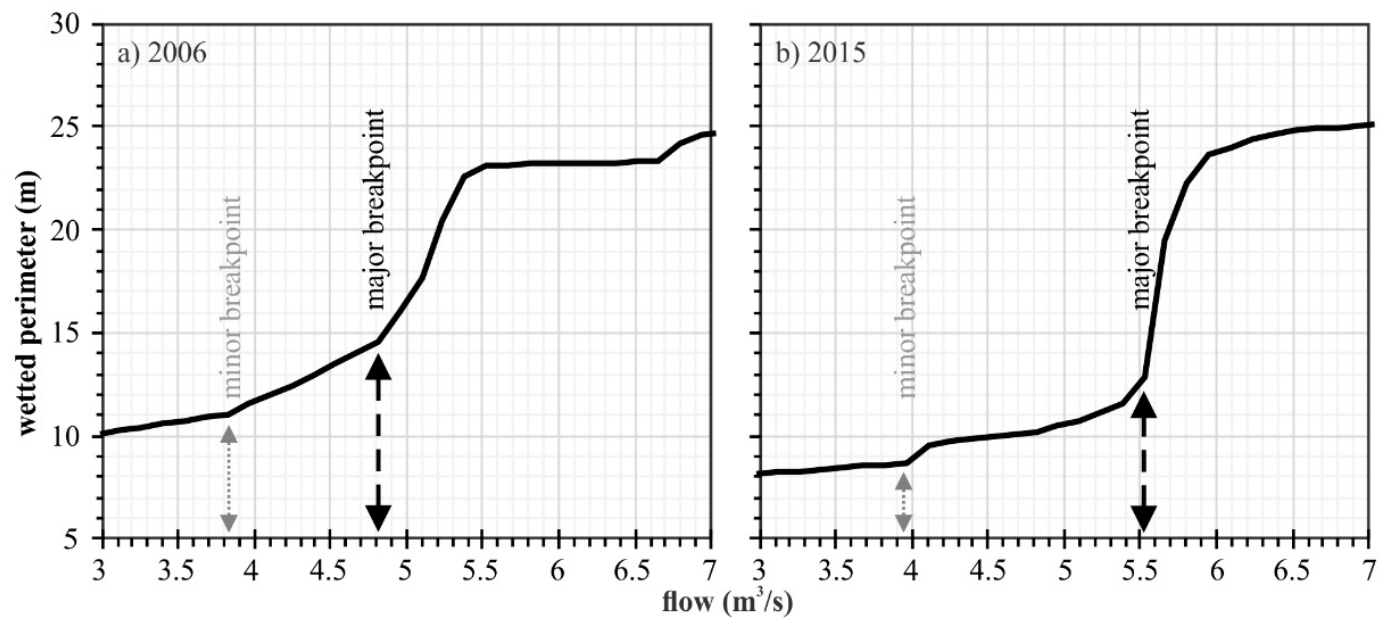

Figure 5. The geomorphic bankfull capacity enlarged from a pre-hydrologic modification flow of about $3.9 \mathrm{~m}^{3} / \mathrm{s}$ to a post-hydrologic modification flow of about $4.8 \mathrm{~m}^{3} / \mathrm{s}$ during the (a) 2006 baseline survey and about $5.5 \mathrm{~m}^{3} / \mathrm{s}$ during the $(\mathbf{b})$ repeat survey.

Meas. Modified: 1.5-Yr Flood (1995-2015)

Meas. Modified: 1.5-Yr Flood (1970-2015)

Meas. Modified: 1.5-Yr Flood (1987-2015)

Effective Discharge (1987-2015)

W. P. - Flow Curve Major Break (2015)

Visual Bankfull Indicators (2015)

W.P. - Flow Curve Major Break (2006)

W.P. - Flow Curve Minor Break (2006 \& 2015)

Sim. Natural: 1.5-Yr Flood (1995-2015)

Ref. Watershed Norm.: 1.5-Yr Flood (1965-2015)

WY Regional Regression: 1.5-Yr Flood $(<2000)$

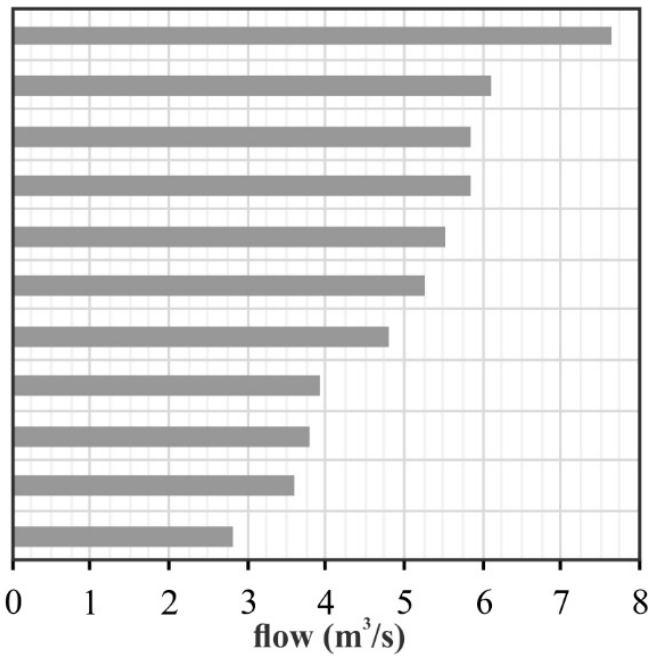

Figure 6. Comparison of bankfull flow estimates. Methods included annual peak in daily average flow data for 1.5-year flood flow estimates, visual field indicators, wetted perimeter-flow curve minor and major breakpoints, Wyoming regional regression, and effective discharge.

The range of bankfull flow estimates, from 2.8 to $7.6 \mathrm{~m}^{3} / \mathrm{s}$, is large (Figure 6). This variability indicated the potential for a future, unstable, hydrologically modified flow regime. Since the 1.5-year flood flow suggests the tendency of the geomorphic bankfull capacity, it was selected as the main criterion for assessing future channel stability. Assuming dam regulation of the upstream structures could be made to accommodate a desired hydrology, a magnitude of $5.7 \mathrm{~m}^{3} / \mathrm{s}$ was selected as the desired 1.5-year flood flow that would limit future channel change. Namely, this magnitude is between the 2015 geomorphic bankfull capacity indicated by the wetted perimeter-flow curve's major breakpoint of $5.5 \mathrm{~m}^{3} / \mathrm{s}$ (Figure 5) and the 1987-2015 measured modified flow regime 1.5-year flood flow of $5.8 \mathrm{~m}^{3} / \mathrm{s}$ (Figure 6). The 2-year, 5-year, and 20-year floods were selected by increasing the 1.5-year flood flow magnitude at similar percent increase intervals to the simulated natural flow flood recurrence interval percent increases (Table 4). 
Table 4. Recurrence intervals used to estimate a new, stable, modified flow regime.

\begin{tabular}{|c|c|c|c|c|c|}
\hline $\begin{array}{l}\text { Recurrence } \\
\text { Interval }\end{array}$ & $\begin{array}{l}\text { Sim. Natural Flow } \\
\left(\mathrm{m}^{3} / \mathrm{s}\right)\end{array}$ & $\begin{array}{c}\text { Percent Increase } \\
(\%)\end{array}$ & $\begin{array}{l}\text { Meas. Modified Flow } \\
\left(\mathrm{m}^{3} / \mathrm{s}\right)\end{array}$ & $\begin{array}{l}\text { Meas. Modified Flow } \\
\left(\mathrm{m}^{3} / \mathrm{s}\right)\end{array}$ & $\begin{array}{l}\text { New, Stable, Modified Flow } \\
\left(\mathrm{m}^{3} / \mathrm{s}\right)\end{array}$ \\
\hline & 1995-2015 & - & 1995-2015 & 1987-2015 & 2025-2045 \\
\hline 1.1 & 2.26 & - & 3.68 & 4.53 & 3.4 \\
\hline 1.5 & 3.77 & 67 & 7.62 & 5.83 & 5.7 \\
\hline 2 & 4.59 & 22 & 7.96 & 7.59 & 6.8 \\
\hline 5 & 5.58 & 22 & 9.26 & 9.03 & 8.2 \\
\hline 20 & 6.91 & 22 & 10.73 & 10.22 & 9.9 \\
\hline
\end{tabular}

The new, stable, modified flow regime incorporated two major components, the flow attributes of the existing geomorphic bankfull capacity of the channel (Table 4) and the individual attributes of the simulated natural flow regime (Table 3). The first major component, the recurrence intervals (RIs), were grouped into peak flow size classes. The peak flow size classes included no overbank flows (no floods) with 1- to 1.5-year RI, small overbank flows (small floods) with 1.5- to 5-year RIs, and large overbank flows (large floods) with 5- to 20-year RIs (Figure 7). The magnitudes of each peak flow were based on the existing geomorphic bankfull capacity (Table 4). One indicator to predict the size class of peak flow is the peak Snow Water Equivalent (SWE) of the snowpack measured at nearby SNOTEL stations (Figure 1). The duration, rise rates, fall rates, and timing were based on the simulated natural flow regime (Table 3). The simulated natural flow regime indicated that the rising limb would begin no earlier than mid-April; the peak would occur, on average, near early June but no earlier than mid-May and no later than early July, and the falling limb would end no later than mid-August (Figure 7).

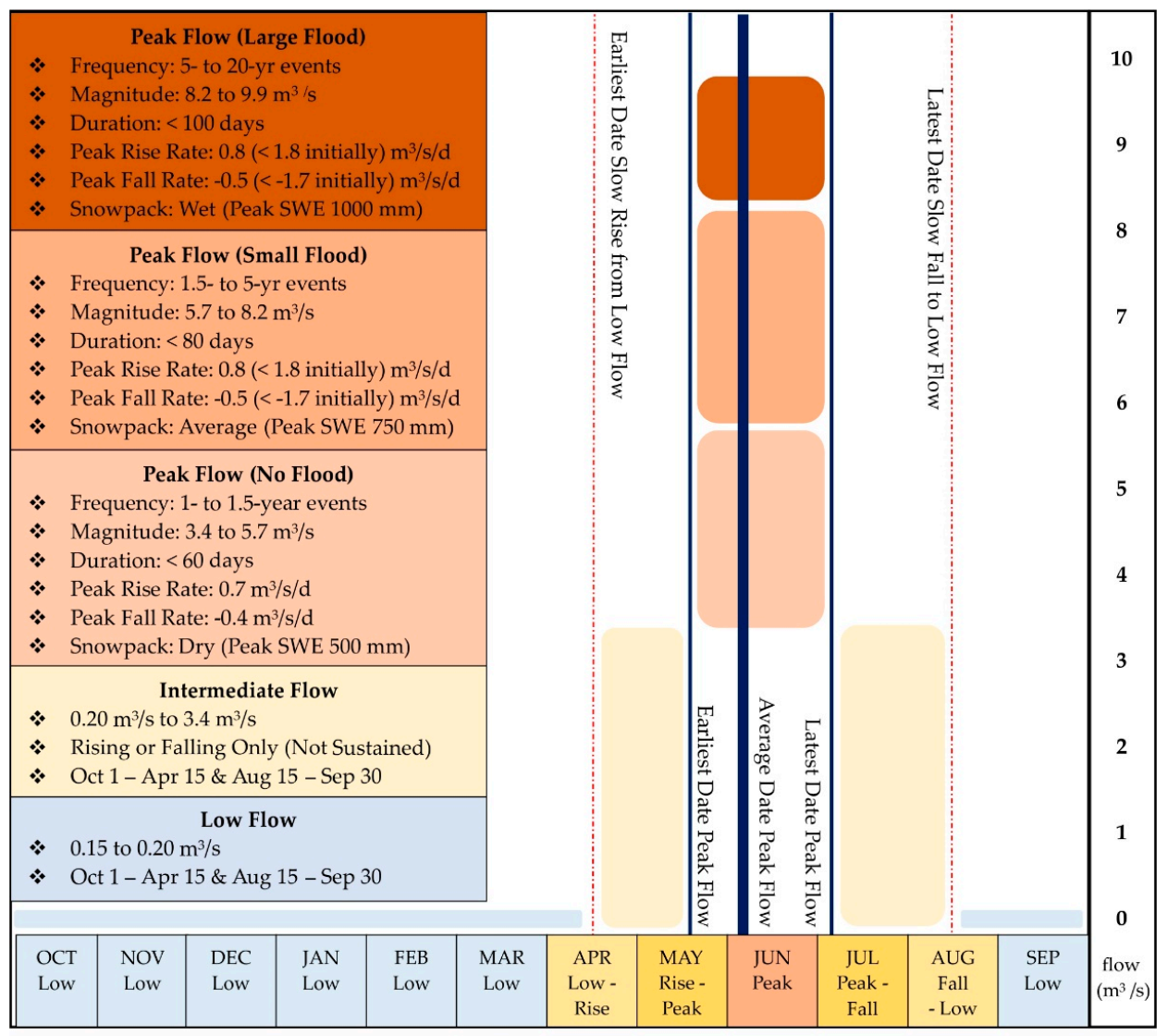

Figure 7. A visual summary of the new, stable, modified flow regime based on the existing geomorphic bankfull capacity and the simulated natural flow regime. The individual flow attributes were defined for peak flows (no flood, small flood, and large flood), intermediate flows, and low flows. The $x$-axis provides an indication of the flow attribute timing and the $y$-axis provides an indication of the flow attribute magnitude. Following a stable, modified flow regime for a long-term period would be one tool to promote future channel stabilization. 
In addition to peak flow attributes, the intermediate and low flows were estimated based on the simulated natural flow regime (Table 3). The intermediate flows were restricted to the late spring and the late summer during the rising and falling limb periods (Figure 7). Moreover, these flows were simulated only as transition flows, meaning they were not sustained for long durations, but were instead either falling or rising. The magnitudes of the intermediate flows were between low flow and the 1.1-year RI peak flow. The low flow magnitude was approximated to be $0.15 \mathrm{~m}^{3} / \mathrm{s}$, which was slightly greater than the 7-day low flow of $0.13 \mathrm{~m}^{3} / \mathrm{s}$ (Table 3). Together the peak, intermediate, and low flow attributes provided a foundation for a new, stable, modified flow regime to promote future channel stability (Figure 7).

\section{Discussion}

To assess hydrologic response in a hydrologically modified watershed, PUB methods were utilized. This PUB method involved two applications of the PRMS hydrologic model, for reference and study watersheds. Since measured natural-flow data were unavailable at the study watershed, hydrologic model calibration and evaluation could not be performed in the typical way for the study watershed application of the PRMS hydrologic model. Instead, typical calibration and evaluation was conducted only for reference watershed hydrologic model parameterization. This allowed an overall model performance for the reference watershed application of the PRMS hydrologic model, which was an NSE of 0.89 for calibration and NSE of 0.82 for evaluation. For comparison, twelve applications of the PRMS hydrologic model in the Willamette River basin near the Cascade Range of Oregon, resulted in an NSE ranging between 0.62-0.93 for calibration and 0.58-0.90 for evaluation [19].

Furthermore, the Willamette River study treated five of the 12 applications of the PRMS hydrologic model as ungauged basins to test how well the regionalization method simulated flows in gauged basins, and found acceptable model performance, with an NSE of 0.60-0.76 [19]. Without any further calibration or evaluation, the study watershed application of the PRMS hydrologic model was parameterized using the regionalization method with the unique study watershed parameters and the missing sensitive parameters obtained from calibration of the reference watershed model. Although each PUB method includes an unknown degree of uncertainty, the main uncertainties in this approach were assumed to be minimized by using an adjacent watershed with similar climates, topography, geology, and land cover.

Recognizing the uncertainty, this particular PUB regionalization technique demonstrated its value in producing a long-term dataset of simulated daily average flow. An accurate estimation of the natural flow record is necessary in determining key components of the natural flow regime [17]. The long-term simulated natural daily average flow record at the study watershed did successfully identify the degree to which each attribute of the natural flow regime was altered (Table 3). While hydrologic modification did illustrate changes, such as flows that were lower with peaks occurring later (Figure 3), part of this difference could have come from the parameterization process that is based on the transfer of parameters calibrated on the reference watershed. As seen in this study, the specific type of flow alteration is dependent on the unique environmental setting and impoundment, diversion, and water collection system operation. This study also found many likenesses to similar studies. For example, the study watershed low flows increased three-fold similar to the 10-fold increase in low flows at the River Ter, UK [9]. The intermediate flows increased similarly to the Milk River, Alberta, as indicated by monthly average flow increases of $2-3$ times [8]. The peak flows increased by nearly doubling, similar to the La Poudre Pass Creek of the Poudre River and Lake Creek of the Arkansas River in Colorado [10,11].

With the change in hydrology, in this study, as well as the many other similar cases, there was an alteration in channel form [7,9-11]. This response is consistent with the qualitative response model and findings of similar trans-basin diversion case studies [5]. In quantifying the hydraulic response of the study watershed hydrologic modification, a key validation in the PUB regionalization technique used in this study was perhaps found, which may provide one more tool for understanding the uncertainty. 
The agreement between the 1.5-year peak flow of the simulated natural flow regime and the flow associated with the minor breakpoint found consistently in the sensitive reach cross-sections (Figure 5) appears to provide some validation for this PUB regionalization technique providing an adequate simulation of the natural flow regime.

In turn, characterizations of the simulated natural flow regime and the measured modified flow regime provided validation for the capability of the hydraulic simulation method. As noted above, there was agreement between simulated natural flow attributes (i.e., 1.5-year flood flow) and remnant minor breakpoints on the wetted-perimeter-flow curves (Figure 6). There was agreement between measured modified flow attributes (i.e., 1-5-year flood flow) and major breakpoints in the sense that the channel bankfull capacity increase tracks the increasing 1.5-year flood flow (Figure 6). With these consistencies, the hydraulic response method of collecting baseline and repeat geometry data and parameterization of the HEC-RAS model was deemed adequate.

Lastly, as indicated by the linkage between hydrology and hydraulics, a stable flow regime was found to be an integral component when considering future channel stabilization. Since a channel adjusts to both its water and sediment supplies, the other key factor for considering future channel stabilization is the sediment regime. In this case, it was assumed that the increased flows from augmentation outweighed the sediment deficit from the reservoir storage, dam, and outlet works. Thus, this approach focuses on the sediment transport relation to a stable flow regime, while also acknowledging the need for a better understanding of the changing sediment regime in hydrologically modified systems.

\section{Conclusions}

The linking of hydrologic and hydraulic data with models provided the foundation needed to understand the changes induced by the hydrologic modification of a transboundary watershed where collection systems export water. The Prediction in Ungauged Basin framework was used to simulate mean daily flows to evaluate the flow conditions of the natural flow regime and the corresponding flow alterations. Peak flows are less and occur later, with lower base flows and lower ramping (rise and fall) rates due to flow modification. Investigating a sensitive reach within a hydrologically modified system using hydraulic modeling demonstrated a change in the response of the system that would have occurred under natural flow conditions. The relation of hydrology and channel form is integral for improving environmental sustainability at complex, hydrologically modified systems. The design of a new, stable, modified flow regime demonstrated the potential for promoting a stable channel form. Lower flows are required at various recurrence intervals to maintain a new stable channel environment.

Author Contributions: Conceptualization, T.J.C. and S.R.F.; methodology, T.J.C. and S.R.F.; software, T.J.C.; formal analysis, T.J.C.; data curation, T.J.C.; writing—original draft preparation, T.J.C.; writing—review and editing, T.J.C. and S.R.F.; visualization, T.J.C. and S.R.F.; supervision, S.R.F. All authors have read and agreed to the published version of the manuscript.

Funding: This research received no external funding.

Acknowledgments: Thank you to Dave Gloss, Bryce Marston, Katie Buchan, Dan Cenderelli, Liz Schnackenberg, Katie Soulliere, John Stednick, and Greg Butters for all their time and expertise dedicated to this project. Additionally, thank you to the collaborators at Cheyenne Board of Public Utilities for their essential insights and ongoing support for the project.

Conflicts of Interest: The authors declare no conflict of interest.

\section{Appendix A}

The appendix presents the timeline of flow manipulation in the study basin. 
Table A1. Timeline of hydrologic modification at the study watershed.

\begin{tabular}{|c|c|c|c|}
\hline Event & Description & Location & Timing \\
\hline $\begin{array}{l}\text { Stage I of the } \\
\text { Cheyenne-Little Snake } \\
\text { River Project }\end{array}$ & $\begin{array}{l}\text { Dam, reservoir, water } \\
\text { collection system, and } \\
\text { pipeline constructed and } \\
\text { put into operation }\end{array}$ & Study Watershed & $\begin{array}{l}\text { 1960s, full operation } \\
\text { approx. } 1965\end{array}$ \\
\hline $\begin{array}{l}\text { Stage II of the } \\
\text { Cheyenne-Little Snake } \\
\text { River Project }\end{array}$ & $\begin{array}{l}\text { Dam, reservoir, water } \\
\text { collection system, and } \\
\text { pipeline enlarged and } \\
\text { put into operation }\end{array}$ & Study Watershed & $\begin{array}{l}\text { 1980s, full operation } \\
\text { approx. } 1987\end{array}$ \\
\hline Measured Flow Records & $\begin{array}{c}\text { Complete flow record } \\
\text { available from CBPU } \\
\text { and WSEO }\end{array}$ & Study Watershed Outlet & 1995-2005 \\
\hline Measured Flow Records & $\begin{array}{c}\text { USGS flow station } \\
\text { moved to upstream of } \\
\text { Hog Park } \\
\text { Creek confluence }\end{array}$ & $\begin{array}{c}\text { Reference } \\
\text { Watershed Outlet }\end{array}$ & 1965-present \\
\hline $\begin{array}{l}\text { Measured Channel } \\
\text { Geometry and Simulated } \\
\text { Channel Hydraulics }\end{array}$ & $\begin{array}{l}\text { Baseline survey, } \\
\text { Repeated survey }\end{array}$ & $\begin{array}{l}\text { Study Watershed } \\
\text { Sensitive Reach }\end{array}$ & 2006, 2015 \\
\hline Simulated Flow Records & $\begin{array}{c}\text { Run-in period, } \\
\text { evaluation period, and } \\
\text { calibration period }\end{array}$ & $\begin{array}{c}\text { Reference } \\
\text { Watershed Outlet }\end{array}$ & $\begin{array}{c}\text { 1987-1994, 1995-2004, } \\
\text { 2005-2014 }\end{array}$ \\
\hline Simulated Flow Records & $\begin{array}{l}\text { Simulated natural } \\
\text { flow record }\end{array}$ & Study Watershed Outlet & 1995-2015 \\
\hline
\end{tabular}

\section{Appendix B}

The appendix presents the optimized parameter values estimated for the reference watershed.

Table A2. The final 21 sensitive parameters values optimized for the reference watershed, as outlined in Table 2.

\begin{tabular}{ccc}
\hline Calibration Data & Parameter & Value(s) \\
\hline & dday_intcp & $9.964,9.998,9.968,-1.949,2.165$, \\
(Jan.-Dec.) & $-13.367,-32.135,-14.134,4.305$, \\
Average monthly SR & & $9.998,9.07,10$ \\
\cline { 2 - 3 } & tmax_index (Jan.-Dec.) & $\begin{array}{c}66.473,40.08,101.567,45.131, \\
62.531,97.441,92.825,68.718, \\
107.316,101.907,100.899,74.125\end{array}$ \\
\hline Basin average monthly ET & & $0.006,0.019,0.035,0.012,0.012$, \\
& jh_coef & $0.01,0.02,0.054,0.056,0.021$, \\
& (Jan.-Dec.) & $0.005,0.005$ \\
\hline Average annual flow, & adjust_rain & $0.831,0.761,0.199,0.043,0.998$, \\
Average monthly flow, and & (Jan.-Dec.) & $0.378,0.005,0.929,0.155,0.021$, \\
Monthly average flow & adjust_snow & $0.893,0.126$ \\
\cline { 2 - 3 } & (Jan.-Dec.) & $0.377,0.997,0.14,0.006,0.008$, \\
& & $0.009,0.04,0.452,0.996,0.004$, \\
& & $0.004,0.002$ \\
\hline
\end{tabular}


Table A2. Cont.

\begin{tabular}{|c|c|c|}
\hline Calibration Data & Parameter & Value(s) \\
\hline \multirow{10}{*}{ Daily flow } & $\begin{array}{l}\text { adjmix_rain } \\
\text { (Jan.-Dec.) }\end{array}$ & $\begin{array}{c}2.922,0.569,0.63,0.453,1.663 \\
2.737,2.033,1.243,0.807,0.131 \\
0.993,2.943\end{array}$ \\
\hline & $\begin{array}{l}\text { cecn_coef } \\
\text { (Jan.-Dec.) }\end{array}$ & $\begin{array}{c}4.735,9.653,2.388,0.076,5.752 \\
9.531,7.18,8.745,0.969,0.884 \\
0.087,8.196\end{array}$ \\
\hline & emis_noppt & 1.000 \\
\hline & free_h20cap & 0.110 \\
\hline & potet_sublim & 0.154 \\
\hline & slowcoef_lin & 0.003 \\
\hline & slowcoef_sq & 0.004 \\
\hline & snowinfil_max & 2.695 \\
\hline & $\begin{array}{l}\text { tmax_allrain } \\
\text { (Jan.-Dec.) }\end{array}$ & $\begin{array}{c}89.431,65.778,65.409,52.916,68.81 \\
81.706,60.467,68.192,75.843 \\
82.594,63.749,85.035\end{array}$ \\
\hline & tmax_allsnow & 34.403 \\
\hline \multirow{2}{*}{ Peak flow } & smidx_coef & 0.005 \\
\hline & smidx_exp & 0.303 \\
\hline \multirow{4}{*}{ Low flow } & gwflow_coef & 0.001 \\
\hline & soil2gw_max & 0.050 \\
\hline & ssr2gw_exp & 0.005 \\
\hline & ssr2gw_rate & 0.026 \\
\hline
\end{tabular}

\section{References}

1. Graf, W.L. Dam nation: A geographic census of American dams and their large-scale hydrologic impacts. Water Resour. Res. 1999, 35, 1305-1311. [CrossRef]

2. Poff, N.L.; Allan, J.D.; Bain, M.B.; Karr, J.R.; Prestegaard, K.L.; Richter, B.D.; Sparks, R.E.; Stromberg, J.C. The natural flow regime. Bioscience 1997, 47, 769-784. [CrossRef]

3. Williams, G.P.; Wolman, M.G. Downstream Effects of Dams on Alluvial Rivers; U.S. Geological Survey Professional Paper 1286; United States Goverment Printing Office: Washington, DC, USA, 1984.

4. Andrews, E.D. Downstream effects of Flaming Gorge reservoir on the Green River, Colorado and Utah. Geol. Soc. Am. Bull. 1986, 97, 1012-1023. [CrossRef]

5. Brandt, S.A. Classification of geomorphological effects downstream of dams. Catena 2000, 40, 375-401. [CrossRef]

6. Gilliam, E.A. Assessing Channel Change and Bank Stability Downstream of a Dam, Wyoming. Master's Thesis, Colorado State University, Fort Collins, CO, USA, 2011.

7. Kellerhals, R.; Church, M.; Davies, L.B. Morphological effects of interbasin river diversions. Can. J. Civ. Eng. 1979, 6, 18-31. [CrossRef]

8. Bradley, C.; Smith, D.G. Meandering channel response to altered flow regime: Milk River, Alberta and Montana. Water Resour. Res. 1984, 20, 1913-1920. [CrossRef]

9. Petts, G.E.; Pratts, J.D. Channel changes following reservoir construction on a Lowland English River. Catena 1983, 10, 77-85. [CrossRef]

10. Wohl, E.; Dust, D. Geomorphic response of a headwater channel to augmented flow. Geomorphology 2012, 138.1, 329-338. [CrossRef]

11. Dominick, D.S.; O'Neill, M.P. Effects of flow augmentation on stream channel morphology and riparian vegetation: Upper Arkansas River basin, Colorado. Wetlands 1998, 18, 591-607. [CrossRef] 
12. Stromberg, J.C.; Patten, D.T. Response of Salix lasiolepis to augmented stream flows in the upper Owens River. Madrono 1992, 39, 224-235.

13. Hrachowitz, M.; Savenije, H.H.G.; Blöschl, G.; McDonnell, J.J.; Sivapalan, M.; Pomeroy, J.W.; Arheimer, B.; Blume, T.; Clark, M.P.; Ehret, U.; et al. A decade of Predictions in Ungauged Basins (PUB)—A review. Hydrol. Sci. J. 2013, 58, 1198-1255. [CrossRef]

14. England, J.F.; Cohn, T.A.; Faber, B.A.; Stedinger, J.R.; Thomas, W.O., Jr.; Veilleux, A.G.; Kiang, J.E.; Mason, R.R., Jr. Guidelines for determining flood flow frequency-Bulletin 17C (ver. 1.1, May 2019). US Geol. Surv. Tech. Methods 2018, 4(B5). [CrossRef]

15. Miller, K.A. Peak-flow characteristics of Wyoming streams. Water Resour. Investig. Rep. 2003, 4107.

16. Sanborn, S.C.; Bledsoe, B.P. Predicting Streamflow Regime Metrics for Ungauged Streams in Colorado, Washington, and Oregon. J. Hydrol. 2006, 325, 241-261. [CrossRef]

17. Carlisle, D.M.; Falcone, J.; Wolock, D.M.; Meador, M.R.; Norris, R.H. Predicting the natural flow regime: Models for assessing hydrological alteration in streams. River Res. Appl. 2009, 26, 118-136. [CrossRef]

18. Merz, R.; Blöschl, G. Regionalisation of catchment model parameters. J. Hydrol. 2004, 287, 95-123. [CrossRef]

19. Chang, H.; Jung, I. Spatial and temporal changes in runoff caused by climate change in a complex large river basin in Oregon. J. Hydrol. 2010, 388, 186-207. [CrossRef]

20. Maheshwari, B.L.; Walker, K.F.; McMahon, T.A. Effects of regulation on the flow regime of the River Murray, Australia. Regul. Rivers: Res. Manag. 1995, 10, 15-38. [CrossRef]

21. Fassnacht, S.R. A multi-channel suspended sediment transport model for the Mackenzie Delta, NWT. J. Hydrol. 1997, 197, 128-145. [CrossRef]

22. Parker, G.W.; Armstrong, D.S.; Richards, T.A. Comparison of Methods for Determining Streamflow Requirements for Aquatic Habitat Protection at Selected Sites on the Assabet and Charles Rivers, Eastern Massachusetts, 2000-02: U.S. Geological Survey Scientific Investigations Report 2004-5092, 72 p. 2004. Available online: https://pubs.usgs.gov/sir/2004/5092/ (accessed on 27 April 2020).

23. Atwood, W.W. Records of Pleistocene Glaciers in the Medicine Bow and Park Ranges. J. Geol. 1937, 45-2, 113-140. [CrossRef]

24. Houston, R.S.; Graff, P.J. Geologic Map of Precambrian rocks of the Sierra Madre, Carbon County, Wyoming, and Jackson and Routt Counties, Colorado. U.S. Geological Survey Miscellaneous Investigations Series Map I-2452; 1995; ISBN 978-0-607-79599-8. Available online: https:/pubs.usgs.gov/imap/2452/report.pdf (accessed on 27 April 2020).

25. NRCS National Water and Climate Center. Available online: https://www.wcc.nrcs.usda.gov/ (accessed on 26 November 2019).

26. Clark, M.L.; Eddy-Miller, C.A.; Mast, M.A. Environmental Characteristics and Water-Quality of Hydrologic Benchmark Network Stations in the West-Central United States; U.S. Geological Survey Circular 1173-C; USGS: Reston, VA, USA, 2000; Volume 115.

27. Leavesley, G.H.; Lichty, R.W.; Troutman, B.M.; Saindon, L.G. Precipitation-Runoff Modeling System: User's Manual; US Geological Survey Water Resources Investigation Report 83-4238; USGS: Reston, VA, USA, 1983; Volume 207.

28. Markstrom, S.L.; Regan, R.S.; Hay, L.E.; Viger, R.J.; Webb, R.M.T.; Payn, R.A.; LaFontaine, J.H. PRMS-IV, the Precipitation-Runoff Modeling System, Version 4; U.S. Geological Survey Techniques and Methods; USGS: Reston, VA, USA, 2015; Book 6, Chap. B7; 158p. [CrossRef]

29. Brunner, G.W. HEC-RAS, River Analysis System User's Manual; US Army Corps of Engineers Hydrologic Engineering Center: Davis, CA, USA, 2001.

30. Wyoming State Engineer's Office. Available online: http://seo.wyo.gov (accessed on 26 November 2019).

31. USGS Water Data for the Nation. Available online: https://nwis.waterdata.usgs.gov (accessed on 26 November 2019).

32. Hay, L.E.; Leavesley, G.H.; Clark, M.P.; Markstrom, S.L.; Viger, R.L.; Umemoto, M. Stepwise, multiple objective calibration of a hydrologic model for a snowmelt dominated basin. J. Am. Water Resour. Assoc. 2006, 42.4, 877-890. [CrossRef]

33. Leaf, C.F.; Brink, G.E. Hydrologic Simulation Model of Colorado Subalpine Forest: U.S. Department of Agriculture; Forest Service Research Paper RM-107; USDA: Washington, DC, USA, 1973; Volume 23.

34. Jensen, M.E.; Haise, H.R. Estimating evapotranspiration from solar radiation: Proceedings of the American Society of Civil Engineers. J. Irrig. Drain. 1963, 89, 15-41. 
35. Viger, R.J.; Leavesley, G.H. The GIS Weasel User's Manual; U.S. Geological Survey Techniques and Methods; USGS: Reston, VA, USA, 2007; Volume 6.

36. NREL National Solar Radiation Database Data Viewer. Available online: https://maps.nrel.gov/nsrdb-viewer/ (accessed on 26 November 2019).

37. USGS Geo Data Portal. Available online: https://cida.usgs.gov/gdp/ (accessed on 26 November 2019).

38. Nash, J.E.; Sutcliffe, J.V. River Flow Forecasting through Conceptual Model. Part 1-A Discussion of Principles. J. Hydrol. 1970, 10, 282-290. [CrossRef]

39. Moriasi, D.N.; Arnold, J.G.; Van Liew, M.W.; Bingner, R.L.; Harmel, R.D.; Veith, T.L. Model evaluation guidelines for systematic quantification of accuracy in watershed simulations. Trans. Asabe 2007, 50, 885-900. [CrossRef]

40. Limerinos, J.T. Determination of the Manning Coefficient from Measured Bed Roughness in Natural Channels. Studies of Flow in Alluvial Channels; U.S. Geological Survey Water-Supply Paper 1898-B; USGS: Reston, VA, USA, 1970.

41. Arcement, G.J.; Schneider, V.R. Guide for Selecting Manning's Roughness Coefficients for Natural Channels and Flood Plains; United States Geol. Survey Water Supply Paper 2339; USGS: Reston, VA, USA, 1989.

42. Chow, V.T. Open-Channel Hydraulics; Mcgraw-Hill: Nez York, NY, USA, 1959.

43. Richter, B.D.; Baumgartner, J.V.; Powell, J.; Braun, D.P. A method for assessing hydrologic alteration within ecosystems. Conserv. Biol. 1996, 10, 1163-1174. [CrossRef]

(C) 2020 by the authors. Licensee MDPI, Basel, Switzerland. This article is an open access article distributed under the terms and conditions of the Creative Commons Attribution (CC BY) license (http://creativecommons.org/licenses/by/4.0/). 